\title{
„Biegnę, więc jestem”. Interpretacja treści prywatnego pamiętnika Harukiego Murakamiego w świetle somaestetyki Richarda Shustermana
}

Adam Kosznicki | Wydział Nauk Społecznych, Uniwersytet Gdański

Słowa kluczowe:

Haruki Murakami, Richard Shusterman,

dokumenty

osobiste,

autoetnografia,

bieganie,

somaestetyka,

doświadczenia

cielesne, sport

\section{Streszczenie}

W niniejszym artykule autor podejmie się zadania interpretacji doświadczeń cielesnych opisanych w prywatnym pamiętniku biegowym japońskiego pisarza Harukiego Murakamiego pod tytułem O czym mówię, kiedy mówię o bieganiu. Ramą teoretyczną dla tego działania będzie zaś somaestetyka - nowy nurt filozoficzno-estetyczny, którego twórcą jest amerykański myśliciel Richard Shusterman. Podane zostaną główne założenia jego koncepcji oraz elementy jej krytyki. Somaestetyka spotkała się z silnym oddźwiękiem i w środowisku badaczy odbierana jest jako nurt dość kontrowersyjny, stąd też jest zarówno wielu jej propagatorów, jak również oponentów. Opinie z obu stron zostały omówione w niniejszym tekście. Tak ujęty przedmiot analizy narzuca dwuczłonową konstrukcję tekstu. W pierwszej z nich czytelnik zapozna się z ogólnym opisem somaestetyki oraz jej podstawowych pojęć i założeń. Następnie w skrócie zostanie scharakteryzowane dzieło literackie H. Murakamiego oraz jego aspekty poddane w dalszej części artykułu głębszej interpretacji. Aby czytelnik mógł zapoznać się bezpośrednio z treścią książki, zacytowano też wybrane jej fragmenty. Całość pracy podsumowują konkluzje związane z tym, jak cała praca Murakamiego odnosi się do myśli Shustermana.

\section{"I run; therefore I am". An interpretation of private diary of Haruki Murakami in light of somaesthetics by Richard Shusterman}

\section{Abstract}

Keywords:

The aim of the article is to interpret embodied experiences described in the book What I talk about when I talk about running by Haruki Murakami. The analytical frame for this task is the new philosophical and aesthetical movement called somaesthetics, invented by an American thinker Richard Shusterman. Not only the main assumptions of this conception, but also elements of its criticism are presented. Soamesethetics has met with strong response among philosophers, and gained both followers and opponents. Opinions of both sides are described in the article. The subject of this paper imposes its structure. In the first part, basic propositions and terms of somaesthetics are introduced. The second part is devoted to the work of H. Murakami and deeper interpretation of chosen excerpts. To familiarize the reader with content of the book selected quotations have been provided. The article ends with recapitulation of the main conclusions concerning the way Murakami's work corresponds to Shusterman's theory. 
Tematem niniejszego artykułu ma być interpretacja doświadczeń cielesnych opisanych w książce O czym mówię, kiedy mówię o bieganiu japońskiego pisarza Harukiego Murakami. Jest to jego pamiętnik poświęcony pasji, jaką są biegi długodystansowe. Przygodę z tym sportem rozpoczął jeszcze na początku lat osiemdziesiątych, mając już ponad trzydzieści lat. Od tego czasu pokonał ponad dwadzieścia maratonów i jeden ultramaraton. W międzyczasie zaczął też zajmować się treningiem triathlonu. Głównym motywem do napisania tej książki była dla H. Murakamiego chęć zrozumienia, czym jest bieganie i jaką pełni rolę $w$ jego życiu. Jest ona zarówno dziennikiem treningowym, zbiorem wspomnień, wycinkiem biografii, ale także zapisem osobistych doświadczeń fizycznych i duchowych. Z socjologicznego punktu widzenia może być więc zaklasyfikowana jako forma dokumentu osobistego, który w tym wypadku przyjmuje formę literacką. Ma ona charakter danych zastanych, to znaczy powstałych bez jakiejkolwiek ingerencji badacza.

Na wybór tematu niniejszego artykułu wpłynęło kilka powodów. Podstawowym jest chęć pokazania, że bieganie nie jest wyłącznie czynnością stricte fizyczną, ale może być też ujmowane jako praktyka społeczno-kulturowa. Opinię taką wyraża między innymi dwoje angielskich badaczy - Jacquelyn Allen-Collinson oraz John Hockey. Analizując ten sport z punktu widzenia fenomenologii socjologicznej, twierdzą oni, że praca wytrzymałościowa (enduring) - jako indywidualny sposób bycia-w-świecie (being-in-the-world) - nie jest wyłącznie fenomenem indywidualnym, lecz jest podzielana i komunikowana pomiędzy poszczególnymi biegaczami długodystansowymi, przez co konstytuuje swoistą interakcyjną praktykę subkulturową (Allen-Collinson, Hockey 2015a: 2). Taki stan rzeczy otwiera tym samym możliwość eksploracji socjologicznej tego terytorium. Ci sami autorzy wyrażają również opinię, iż tego typu tematyka nie była do tej pory zbyt silnie eksplorowana przez badaczy społecznych. Według nich obecnie skąpy jest zbiór literatury socjologicznej, w której dokonywano by pogłębionych analiz zmysłowych sposobów angażowania się ludzi w sport, czas wolny czy przestrzenie ich zajęć (Allen-Collinson, Hockey 2015b: 2). Teza ta ma zastosowanie nie tylko do realiów zachodnich, lecz również polskich. W wydanej niedawno książce poświęconej socjologii sportu można znaleźć opinię, iż literatura dotycząca socjologicznych analiz sportu wciąż pozostaje dość uboga (Jakubowska, Nosal, red., 2017: 8). $Z$ tego też względu niniejszy artykuł byłby - w pewnym przynajmniej zakresie - wypełnieniem tejże luki.

Poza tym dociekania dokonane $w$ tej pracy są nowatorskie pod kątem metodologicznym i empirycznym. Co do aspektu metodologicznego, to wspomniani wcześniej J. Allen-Collinson oraz J. Hockey uważają, że prowadzenie dzienniczka treningowego może być traktowane jako forma badań autoetnograficznych. Badacze są biegaczami i w jednym ze swoich projektów empirycznych wykorzystali prowadzone przez siebie dzienniczki treningowe (por. Allen-Collinson, Hockey 2015b: 8). W tym miejscu materiałem empirycznym będzie pamiętnik biegowy znanego pisarza. Dzięki temu możliwe będzie poznanie przeżyć wewnętrznych związanych z uprawianą praktyką 
oraz ich kontekstu społecznego. Jeśli zaś chodzi o nowatorstwo empiryczne, to w artykule poruszone zostaną wątki doświadczania temperatury, co do tej pory nie było zbyt intensywnie badane. W literaturze można spotkać opinię, że relatywny niedostatek badań socjologicznych o przeżywanym doświadczeniu gorąca jest zaskakujący, zważywszy na istotną rolę percepcji temperatury w codziennym życiu, w tym w sporcie i kulturze fizycznej (Allen-Collinson et al. 2016: 4).

Dla analiz socjologiczno-literackich dokonanych tutaj bazą teoretyczną ma być somaestetyka (zwana też czasami somatoestetyką, por. Małecki 2007: 813) - dziedzina filozofii stworzona i rozwijana przez Richarda Shustermana. Według tego badacza:

Somaestetyka może być wstępnie zdefiniowana jako krytyczne, melioratywne badanie doświadczenia oraz użycie ciała jako miejsca zmysłowo-estetycznego zrozumienia (aisthesis) i kreatywnego modelowania siebie (self-fashioning). Dlatego też poświęcona jest wiedzy, dyskursom, praktykom oraz cielesnym dyscyplinom, które strukturyzują troskę o ciało lub mogą je ulepszyć (Shusterman 1999: 302).

Jak łatwo zauważyć, w centrum zainteresowania tej nowej dyscypliny znajduje się ciało. Jest to podejście sprzeczne z dotychczasową tradycją humanistyczną, która abstrahowała od problemów fizycznej egzystencji człowieka, skupiając się - zamiast tego - na aspektach stricte duchowych. Jak pisze Shusterman,

Najogólniej rzecz biorąc, somaestetyka zajmuje się ciałem jako ośrodkiem zmysłowo-estetycznego wartościowania (aisthesis) i twórczej autokreacji. Jako teoretyczna i zarazem praktyczna dyscyplina doskonaląca, jest ona nakierowana na wzbogacenie nie tylko naszej abstrakcyjnej, dyskursywnej wiedzy o ciele, lecz także na polepszenie somatycznego, przeżywanego przez nas doświadczenia i jego interpretacji (Shusterman 2007: 47).

Autor tej nowej dyscypliny filozoficznej przypisuje jej też określone zadania do wykonania, a najważniejszym z nich ma być poprawa ogólnej egzystencji człowieka, przy czym dobrostan ducha ma być osiągnięty przez stworzenie harmonii w funkcjonowaniu ciała. Widać w tym stanowisku poniekąd powiązanie z antyczną formułą Mens sana in corpore sano, której autorem jest rzymski poeta Juwenalis'. Shusterman rozciąga jednak efekty uprawiania somaestetyki nie tylko na jednostkę, lecz także na całe społeczeństwo. Pisze o tym w ten sposób:

Kluczowym punktem somaestetyki [...] nie jest poprawa działania ciała jako cel sam w sobie, ale jej wkład w rozwój całej osoby oraz ewentualnie w rozwój całego społeczeństwa, w którym taka osoba żyje. Zamiast ograniczać się jedynie do opisywania kulturowych praktyk dotyczących ciała, somaestetyka jest sygnałem wzywającym do „ich porównawczej krytyki" na warunkach ich rywalizujących metod (Shusterman 2002: 107).

\footnotetext{
' Słynna łacińska sentencja tłumaczona w języku polskim jako „W zdrowym ciele zdrowy duch” (patrz: https:// pl.wikipedia.org/wiki/Mens_sana_in_corpore_sano, dostęp 24.03.2017 r.).
} 
Krytyka ta ma odnosić się nie tylko do teorii i metod, lecz również konkretnych praktyk kulturowych. Narcystyczne samozadowolenie nie jest do końca tym, co jest pożądane; ćwiczenie w samozagłębianiu się (self-absorption) nie jest rozwijane jako cel sam w sobie, ale by poprawić to, czym dana osoba może być i co robić, z tego zaś powodu - kim może być i co robić dla innych (Shusterman 2002: 108).

Warto też pochylić się nad źródłosłowem tego nowego pojęcia, aby móc głębiej zrozumieć jego znaczenie. Nazwa "somaestetyka” wywodzi się od greckich słów soma (ciało) oraz estetyka (dział filozofii zajmujący się pięknem i doświadczeniem zmysłowym w ogólności). Jest formą uprawiania estetyki i koncentruje się na ciele jako jądrze doświadczenia zmysłowego człowieka. Według R. Shustermana w naukach humanistycznych dokonał się negatywny w skutkach rozdział pomiędzy soma a psyche (por. Shusterman 2007: 46). Współczesna filozofia i inne nauki o człowieku afirmuje ten drugi element ludzkiej egzystencji, traktując go jako podstawowy, przy jednoczesnym zdeprecjonowaniu pierwszego. $Z$ tego też względu postawił on sobie za cel przezwyciężenie tego negatywnego dualizmu, zaś narzędziem do jego realizacji ma być właśnie somaestetyka. Ciało dla R. Shustermana nie jest jedynie martwym zbiorem tkanek (z tego względu unika on terminu body, który w języku potocznym kojarzy się raczej z martwym obiektem), jest natomiast aktywnym podmiotem poznawania zarówno swojego psychicznego wnętrza, jak również otaczającego świata.

Omawiany autor zarzuca też współczesnym myślicielom, że zbyt dużą uwagę poświęcają badaniu tekstów, przez co w znaczny sposób alienują się od świata, który ich otacza. $Z$ tego względu nie tylko ogranicza to ich możliwości poznawcze, ale też oddala ich od codziennego życia. Jak sam zauważa,

\begin{abstract}
Kiedy zwracam uwagę na imperializm słowa pisanego względem somaestetyki, nie neguję wartości i konieczności słów w prowadzeniu nas do i zarazem przez pewne eksploracje somatyczne. Po prostu argumentuję za większym rozpoznaniem niewerbalnych doświadczeń i praktyk. [...] Wszyscy ludzie zwracają większą uwagę na słowa i przedmioty zewnętrzne zamiast na ich własne doświadczenia cielesne, istnieją też doskonałe dowody ewolucyjne na naszą pierwotną i dominującą potrzebę, by skierować nasze spojrzenie na zewnątrz i być zorientowanym językowo. Jednak filozofowie, których uwaga skupiona jest głównie na języku i którzy są zawodowo wynagradzani za czytanie, pisanie i dyskutowanie o tekstach, muszą być uświadomieni o użyciu niewerbalnego doświadczenia i zachowania (Shusterman 2002: 104).
\end{abstract}

Tezy R. Shustermana przedstawione w wielu jego pracach dotyczące zarówno funkcjonowania humanistyki, jak i zadań stawianych somaestetyce znalazły szeroki oddźwięk wśród innych badaczy. Opinie wyrażane przez komentatorów dorobku tego myśliciela były zarówno pozytywne, jak też negatywne. Jeden z nich zauważa, że myśl R. Shustermana stanowi zwrot od rozumienia filozofii jako jałowej rozrywki fotelowej elity (arm-chair elitism) ku filozofii jako sztuce życia (Guerra 2002: 73). Formułując takie zdanie, $z$ jednej strony docenia znaczenie dorobku R. Shustermana we 
współczesnym dyskursie, ale z drugiej - zwraca uwagę na kontrowersyjność jego tez. Do tezy R. Shustermana o rozdziale między cielesnością a życiem duchowym w humanistyce odniosła się z kolei Anna Jamroziakowa. Według niej omawiany autor utrzymuje, że kondycja współczesnej filozofii "ześrodkowanej na języku” nie dysponuje warsztatem badawczym, który pozwoliłby na pełniejsze zreferowanie tego, co zawiera somatyczne i niedyskursywne pole badawcze (Jamroziakowa 2006: 175). Jednak A. Jamroziakowa wskazuje, że w pracach R. Shustermana znaleźć można trzy potencjalne sposoby na wykorzystanie niewyartykułowanych doświadczeń cielesnych. Są to: po pierwsze, wskazanie ciała i związanych z nim doświadczeń jako przedmiotu refleksji; po drugie, skupienie się na procesach kulturowych, w których istotną rolę odgrywają praktyki somatyczne; po trzecie wreszcie, włączenie takich praktyk somatycznych w samą czynność filozofowania (Jamroziakowa 2006: 175). Poza tym wygłaszane są tezy krytyczne wobec samej nazwy "somaestetyka”. Wyrażane są opinie, że termin określający tę nową dyscyplinę jest ezoteryczny i tajemniczy, a przy tym nie jest pozbawiony dwuznaczności (por. Higgins 2002: 86).

W pracach R. Shustermana można znaleźć odwołania do różnych tradycji filozoficznych. Na potrzeby dalszej analizy omówione zostaną inspiracje tego autora dorobkiem Michela Foucaulta, myśli starożytnej i Johna Deweya. Odnośnie pierwszego z nich R. Shusterman stwierdza, że jego wizja filozofii wykraczała daleko poza wąsko rozumianą dyscyplinę akademicką, miała zaś być po prostu sztuką dobrego życia (Shusterman 2010: 35). Z kolei odnośnie inspiracji antykiem opisywany autor powoływał się w rozważaniach między innymi na treść dialogów platońskich, a także nauki Sokratesa (por. Shusterman 2010: 37). Jeżeli chodzi zaś o samą relację między cielesnością a dyskursem filozoficznym w antyku, to jest ona opisywana przez Gustavo Guerrę jak stosunek miłości i nienawiści (2002: 78). Ten autor zauważa, że dla Greków ciało było z jednej strony źródłem bólu, cierpienia oraz błędów w działaniu rozumu, ale z drugiej strony przez swoją przemijalność zwracało uwagę człowieka na nadchodzącą nieuchronnie śmierć. Podobnie rzecz ma się w chrześcijaństwie, gdzie ciało jest $z$ jednej strony przeszkodą w oczyszczeniu duszy, jednak może też stanowić pomocne narzędzie w jej leczeniu. Shusterman opiera się też silnie na pragmatyzmie filozoficznym, a w szczególności myśli Johna Deweya. Odwoływał się też do stworzonego przez Deweya terminu mind-body, który wyrażać miał dwoistość i zarazem jedność natury ludzkiej. Według R. Shustermana

Związek ciało-umysł jest na wskroś bliski i błędem wydaje się mówić o ciele i umyśle, jako o dwóch różnych i niezależnych bytach. Termin ciało-umysł (body-mind) mógłby trafniej wyrażać zasadniczy związek jego składników i mimo to w dalszym ciągu pozostawiać miejsce dla pragmatycznego rozróżnienia między umysłowym i fizycznym aspektem zachowania, oraz dla projektu zwiększenia ich, opartej na doświadczeniu, jedności (Shusterman 2007: 47-48). 
Martin Jay, analizując myśl J. Deweya, zauważa, że według tego autora, aby doświadczenie estetyczne mogło osiągnąć maksimum swojego potencjału, muszą być spełnione trzy warunki. Po pierwsze, nie może być ono doznawane wyłącznie w zamkniętych instytucjach, takich jak galerie, muzea itp.; po drugie, musi wyzbyć się Kantowskiego przeświadczenia o tym, że estetyka ma wyłącznie kontemplatywny i przedstawieniowy (spectatorial) charakter; po trzecie wreszcie, doświadczenie musi być doznawane przez całe ciało, a nie jedynie wyobraźnię czy nawet same zmysły jako receptory bodźców z zewnątrz (Jay 2002: 56). Pierwszy z wymienionych warunków pośrednio koresponduje z tezą omówioną wcześniej, a dotyczącą odejścia od traktowania filozofii jako zamkniętej dyscypliny dostępnej wyłącznie dla wtajemniczonych. Z kolei drugi i trzeci wiążą się już ściśle z problemem mind-body. O wpływie pojmowania doświadczenia estetycznego przez J. Deweya na myśl R. Shustermana pisze również James Johnston (2004: 99), według którego doświadczenie estetyczne jest czymś doznawanym bezpośrednio oraz wiąże się z satysfakcją.

Do tej cechy bezpośredniości odwołuje się zresztą sam R. Shusterman w jednym ze swoich tekstów. Zauważa mianowicie, że to akcentowanie pierwszeństwa i bezpośredniości doświadczenia łączy jego i J. Deweya, jednak stwierdza też, że pojęcia te mają charakter wieloznaczny i ich znaczenie jest zależne od kontekstu, często również ulega zmianom (Shusterman 2004: 109). Podawanym przykładem sytuacji czy raczej formy aktywności, w której można zaobserwować tę bezpośredniość doświadczenia, jest wspinaczka górska:

Doświadczenie estetyczne wspinaczki górskiej (która oczywiście wymaga czasu oraz nieco treningu) oznacza czerpanie przyjemności ze wspinania w trakcie samej wspinaczki, nie wtedy zaś, gdy radość jest odłożona na moment wejścia na górę i delektowania się widokiem (Shusterman 2004: 110).

Twórca somaestetyki wyróżnia trzy jej działy: analityczną, pragmatyczną oraz praktyczną. Pierwsza z nich - zgodnie z jego słowami - „[...] opisuje podstawową naturę cielesnych percepcji oraz praktyk, jak również ich funkcję w naszej wiedzy oraz konstrukcji rzeczywistości" (Shusterman 1999: 304). Ten dział somaestetyki ma charakter opisowy i jego celem jest ustalenie faktów, a nie ich ocena. Związany jest też z kontekstem społecznym funkcjonowania ciała. Jak zauważa Jerold Abrams, „Ciało trudno jest ujmować jako atomistyczne, oderwane czy kulturowo puste. W ujęciu Shustermana jest ono ściśle społeczne, językowe, polityczne i estetyczne, jest również właściwym polem do analizy normatywnej" (Abrams 2004: 245). Inaczej sprawa ma się z somaestetyką pragmatyczną. Ona z kolei artykułuje pewne nakazy i tworzy normy dotyczące posługiwania się ciałem i rozwijania go. Uwzględnia przy tym dokonania somaestetyki analitycznej. W ramach somaestetyki pragmatycznej można wyróżnić metody reprezentacyjne (representational) i przedstawieniowe (experiential). Pierwsze z nich zajmują się eksponowaniem zewnętrznego wyglądu ciała, drugie zaś na estetycznej jakości wewnętrznego doświadczenia (Shusterman 1999: 305). 
Natomiast somaestetyka praktyczna nie ma wymiaru teoretycznego czy oceniającego. Polega na stosowaniu dokonań somaestetyki analitycznej i pragmatycznej w konkretnych działaniach. Zajmuje się w całości dbałością o ciało poprzez zdyscyplinowaną pracę fizyczną, której celem jest udoskonalenie tegoż ciała (Shusterman 1999: 307).

Shusterman często w swoich rozważaniach przytacza przykłady z dziedziny sportu. To właśnie różne dyscypliny sportowe mogą być praktyczną formą realizacji głównych założeń somaestetyki. Omawiany autor, poza podanym wcześniej przykładem wspinacza, opisuje też między innymi pałkarza w baseballu (2007: 57-58), golfistę (1999: 303), osoby uprawiające bodybuilding bądź sztuki walki (1999: 304), a także biegi przełajowe (1999: 306). Zauważa też, że trening sportowy sam w sobie może być formą uprawiania somaestetyki:

Chociaż trening sportowy może być środkiem do osiągnięcia zdrowia, cieszymy się nim samym jako częścią tego, co zdrowie w rzeczywistości oznacza - zdolności czerpania radości z mozolnego ćwiczenia. A samo zdrowie cielesne daje przyjemność nie tylko jako środek do wypracowania innych celów, lecz daje przyjemność ze swej istoty, jako przyjemność przyrodzona (Shusterman 2007: 59).

To z kolei prowadzi nas do treści prozy $\mathrm{H}$. Murakamiego, który jedną ze swoich książek poświęcił właśnie egzystencjalnym, ale również psychologicznym czy socjologicznym aspektom treningu biegania długodystansowego.

Kwestię cielesnych doświadczeń podmiotu można zauważyć w zasadzie na każdej stronie omawianej pracy. Autor opisuje swoje początki w uprawianiu biegania i sytuację życiową, która mu w tym okresie towarzyszyła. Omawia też proces stawania się biegaczem i jak pod wpływem biegania zmienia się jego życie. Cielesność doświadczeń pojawia się w zasadzie $w$ każdym z rozdziałów, jednak szczególnie silnie widać ją chociażby w rozdziale trzecim pod tytułem "Ateny w połowie lata - bieg przez 42 kilometry i 195 metrów po raz pierwszy". Czytelnik w relacjach z kolejnych kilometrów trasy może bardzo dokładnie przekonać się, co czuje osoba pokonująca taki dystans. Co więcej, ze względu na porę roku i miejsce, w którym odbywa się samotna walka pisarza-biegacza staje się jasne, że pokonać trzeba nie tylko sam „królewski dystans", ale też morderczy upał. W dalszej części artykułu podane zostaną wybrane cytaty $z$ analizowanej książki H. Murakamiego dotyczące biegu z Aten do Maratonu. Będą one dość długie, jednak zabieg ten jest podyktowany potrzebą dania czytelnikowi możliwości dogłębnego zapoznania się z procesem opisywania swoich doświadczeń cielesnych i towarzyszących im refleksji egzystencjalnych autora książki. Podane wypowiedzi będą też zinterpretowane w świetle omówionych wyżej rozważań R. Shustermana.

Oto wybrane wypowiedzi, które opisują cielesne aspekty zmagania się z biegiem z Aten do Maratonu: 
Biegnę dalej. Słońce ukazuje się w całej pełni i z niewiarygodną szybkością wznosi się na niebie. Umieram z pragnienia. Nie mam czasu się spocić, bo powietrze jest tak suche, że pot od razu paruje, zostawiając na skórze warstwę soli. Mówi się o »kropelkach potu«, ale nie w Grecji, gdzie pot znika tak szybko, że nie może uformować się w kropelki. Czuję, że od słonego osadu swędzi mnie cała skóra. Kiedy oblizuję wargi, smakują jak pasta z sardeli. Zaczynam marzyć o chłodnym piwie - tak zimnym, że aż parzy. W okolicy nie ma jednak żadnego piwa i muszę się zadowolić wodą z redakcyjnej furgonetki co jakieś pięć kilometrów. Nigdy jeszcze tyle nie wypiłem podczas biegu. [...]

Po trzydziestym kilometrze od morza zaczyna wiać czołowy wiatr, który nasila się wraz ze zbliżaniem się do Maratonu. Wiatr jest tak silny, że szczypie mnie w skórę. Mam wrażenie, że gdybym się odprężył, wiatr zdmuchnąłby mnie z drogi do tyłu. Szosa wspina się łagodnie do góry, a w nozdrzach czuję odległy zapach morza. Do Maratonu wiedzie tylko jeden, prosty jak strzelił, szlak. W tym momencie zaczynam odczuwać prawdziwe zmęczenie. Wypijam mnóstwo wody, ale już po kilku minutach znów chce mi się pić. Zimne piwo byłoby najlepsze.

- Nie - zapomnij o piwie. I zapomnij o słońcu. Zapomnij o wietrze. Zapomnij o artykule, który masz napisać. Skup się na przesuwaniu stóp do przodu, jedna za drugą. Tylko to jest teraz ważne.

Mijam trzydziesty piąty kilometr. Nigdy w życiu nie przebiegłem za jednym razem więcej niż trzydzieści pięć kilometrów, więc wszystko, co jest dalej, to terra incognita. Po lewej stronie wznosi się pasmo kamienistych, surowych gór. Zdają się jałowe i bezużyteczne. Po co właściwie bogowie zadali sobie trud, żeby stworzyć coś takiego? Po prawej ciągną się w nieskończoność oliwkowe gaje. Cały krajobraz pokrywa warstwa białego pyłu. A silny wiatr od morza nie daje za wygraną. O co mu chodzi? Dlaczego musi tak mocno wiać? W okolicach trzydziestego siódmego kilometra zaczynam odczuwać nienawiść do całego świata. Dość tego! Już nie mogę! Całkiem opadłem z sił i dalej nie chcę biec. Czuję się tak, jakbym prowadził samochód z pustym bakiem. Muszę się napić, ale jeśli się teraz zatrzymam i sięgnę po wodę, nie będę już w stanie ruszyć z miejsca. Umieram z pragnienia, ale brakuje mi sił, żeby się napić wody. Przez głowę przebiegają mi tego rodzaju myśli i czuję złość. Wściekam się na owce skubiące radośnie trawę na skrawku łąki obok drogi, wściekam się na fotografa pstrykającego zdjęcia z furgonetki. Trzask migawki działa mi na nerwy. Komu potrzebne są te wszystkie owce? Trzaskanie migawką jest zajęciem fotografa, a owce zajmują się skubaniem trawy - kimże ja jestem, żeby im tego zabronić? Ale tak czy inaczej, wszystko to irytuje mnie niepomiernie. Na skórze pojawiają mi się małe białe bąble od słońca. To zaczyna być absurdalne. Po co komu ten upał?

Mijam czterdziesty kilometr.

Jeszcze tylko dwa. Trzymaj się! - woła radośnie reporter z furgonetki. Łatwo ci mówić, chcę odkrzyknąć, ale nie robię tego. Z nagiego słońca wiszącego na bezchmurnym niebie leje się żar. Jest dopiero trochę po dziewiątej, a czuję się jak w piecu. Pot zalewa mi oczy. Od soli zaczynają szczypać i przez chwilę nic nie widzę. Ocieram pot ręką, ale na dłoni i twarzy mam pełno soli, od której oczy pieką mnie jeszcze bardziej.

Za wybujałą letnią trawą widzę w oddali metę - kolumnę wzniesioną u wjazdu do wsi Maraton. Pojawia się tak nagle, że początkowo nie jestem pewien, czy to naprawdę ona. Jestem szczęśliwy, widząc metę - to nie ulega kwestii - ale zaskoczenie, w jakie wprawia mnie ten widok, wywołuje we mnie z jakiegoś powodu gniew. Ponieważ znajduję się na ostatniej prostej, chcę zebrać siły do ostatniego desperackiego wysiłku i pobiec najszybciej jak 
mogę, ale nogi kierują się własnym rozumem. Zupełnie zapomniałem, jak porusza się własnym ciałem. Każdy mięsień boli mnie tak, jakby pocierano go o zardzewiałą tarkę.

Meta.

Dobiegam wreszcie do końca. Co ciekawe, wcale nie cieszę się ze swojego osiągnięcia. Jedyne, co czuję, to ogromna ulga, że nie muszę już biec. Korzystam z kranu na stacji benzynowej, żeby ochłodzić rozgrzane ciało i zmyć oblepiającą mnie sól. [...]

Bieg z Aten do Maratonu zajął mi 3 godziny i pięćdziesiąt jeden minut. Nie jest to dobry wynik, ale przebiegłem całą trasę o własnych siłach, mając za towarzyszy tylko pędzące auta, niewyobrażalny upał i straszliwe pragnienie. Powinienem chyba być dumny z tego, czego dokonałem, ale teraz mało mnie to obchodzi. Teraz obchodzi mnie tylko świadomość, że nie muszę już przebiec ani kroku.

Uff! Już wcale nie musze biegać (Murakami 2010: 70-75).

W podanych fragmentach można znaleźć trzy główne wątki, które poddane zostaną dalszej analizie - dialog wewnętrzny biegacza związany z doświadczeniem wysiłku, walka z temperaturą oraz percepcja otoczenia. Odnośnie pierwszej z tych kwestii, to należy zauważyć, że w wypowiedziach omawianego autora jest pewna tendencja, która wskazuje na narastający poziom irytacji związany z biegiem. Murakami początkowo wydaje się osobą zrelaksowaną i usatysfakcjonowaną biegiem, by z każdym kilometrem stawać się coraz bardziej sfrustrowanym. Nie podaje jednak żadnej konkretnej przyczyny tego stanu rzeczy. Istotne jest to, że autor nie poddaje się wysiłkowi i sięga głęboko do swojej jaźni, aby odeprzeć głosy zwątpienia pojawiające się z jego głowie. Można tego typu proces określić zaczerpniętym z literatury angielskiej terminem okopywania się (digging in). Jego geneza i definicja jest opisywana następująco:

Fraza ta ma zapewne rodowód militarny, gdzie „okopywanie się" jest praktyką podejmowaną przez oddziały w przypadku kontaktu z wrogiem, kiedy kopie się w ziemi narzędziami w celu stworzenia konstrukcji obronnych. W kontekście biegania długodystansowego zaś, oznacza ustawianie swojej „świadomości wytrzymałościowej”, aby obronić siebie jako sportowca przed własnymi słabościami pojawiającymi się w obliczu wysiłku, dyskomfortu, bólu oraz całej gamy geograficznych i klimatycznych stresorów (Allen-Collinson, Hockey 2015a: 5).

Można więc stwierdzić, że tego typu ćwiczenie intelektualne jest w pewnym sensie formą realizacji założeń somaestetyki praktycznej. Człowiek przez pracę nad swoim ciałem rozwija też wewnętrzną kondycję mentalną.

Dwa pozostałe motywy z podanego powyżej fragmentu książki, czyli walka z temperaturą oraz percepcja otoczenia, niejako wynikają z pierwszego i ściśle się z nim łączą. Murakami w trakcie swojego wewnętrznego dialogu w zasadzie ciągle mówi o upale albo - jak w cytowanym fragmencie - o tym, jak doświadcza otoczenia. To jego bardzo głębokie skoncentrowanie się na żarze lejącym się z nieba i jego wpływie na bieg można określić jako intensywne ucieleśnienie (intense embodiment). Są to okresy podwyższonej świadomości doświadczenia cielesnego, w tym też doświadczania 
temperatury (Allen-Collinson, Hockey 2017: 5). Łączy się to z rozważaniami R. Shustermana, według którego aktywność fizyczna może pozytywnie wpływać na świadomość i funkcjonowanie umysłu. Może też powodować jego pozytywną transformację. A relacja $\mathrm{H}$. Murakamiego $\mathrm{z}$ biegu do Maratonu jest tego empirycznym przykładem. Autor przez walkę z przeciwnościami trasy biegu sięga do głębi swojej świadomości, przez co rozwija się wewnętrznie i odkrywa nowe przestrzenie swojej psychiki.

Ostatni ze wskazanych wątków występujących w podanym fragmencie to percepcja otoczenia. Autor opisuje elementy krajobrazu, góry, zwierzęta i drogę, które towarzyszą mu w coraz bardziej wyczerpującej ścieżce na szczyty zmęczenia. Stosunek do tych wszystkich obiektów łączy się z opisaną powyżej narastającą frustracją - Murakami wyraźnie daje nam do zrozumienia, że trasa, w którą się wybrał, nie jest dla niego łagodną wycieczką krajoznawczą, lecz coraz bardziej irytującą męczarnią. To nieco paradoksalne, zważywszy na fakt, że powszechnie uważa się krajobrazy greckie za idylliczne przestrzenie, które uwodzą pięknem. Ma to jednak swoje oparcie w badaniach, które mówią, że ludzie różnie percypują otoczenie w zależności od tego, w jakiej sytuacji się znajdują i jakie posiadają przymioty społeczne. To z kolei może generować specyficzne sposoby widzenia, które różnicowane są przez wiek, płeć, narodowość, poziom sprawności, zawód oraz inne czynniki socjologiczne (Allen-Collinson, Hockey 2015b: 6). Takim czynnikiem może być też wykonywanie określonej aktywności fizycznej, w tym na przykład bieganie. Badacze analizujący tę tematykę piszą o tym następująco:

[...] istnieje silne wizualno-dotykowe doświadczenie w sytuacji pokonywania swojej trasy przez biegacza, który zarówno obserwuje wizualnie swoje otoczenie i środowisko, jak też doświadcza czuciowo terenu i żywiołów. Bieganie jest cieleśnie i zmysłowo doświadczane, jako idące dobrze, źle bądź po prostu w porządku. Te kategoryzacje doświadczenia są zakorzenione w zmieniającym się połączeniu cieleśnie odbieranych cech doświadczenia, takich jak płynność ruchu danej osoby, poziomu energii, struktury mięśni oraz sposobów oddychania (Allen-Collinson, Hockey 2015b: 17).

Warto też zwrócić uwagę na fakt, że tego typu wpływ na subiektywnie doświadczane otoczenie ma też znaczenie w szerszym kontekście społecznym, gdyż sposoby patrzenia oddziałują na szersze kręgi społeczne (por. Allen-Collinson, Hockey 2006: 5).

Bieganie to dla $\mathrm{H}$. Murakamiego nie jest doświadczenie wyłącznie cielesne. To również forma medytacji, bycia z samym sobą, czas na refleksję i kontemplację. I to właśnie najsilniej łączy treść omawianej książki z myślą R. Shustermana. Według H. Murakamiego: „Bez względu na to, jak przyziemna wydaje nam się jakaś czynność, jeśli zajmuje nas wystarczająco długo, staje się aktem kontemplacyjnym, a nawet medytacyjnym" (2010: 6). W innym fragmencie autor wprost zauważa, że w trakcie pisania zdał sobie sprawę z tego, że pisanie o bieganiu jest jednocześnie pisaniem o samym sobie: „Zauważyłem, że uczciwe pisanie o bieganiu i uczciwe pisanie o samym sobie 
jest niemal jednym i tym samym" (2010: 7). Poniekąd może być też traktowane jako uprawianie filozofii, gdyż omawiany pisarz mówi:

Choć nie nazwałbym tego "filozofią" per se, w książce tej jest nieco tak zwanych „życiowych nauk". Nie są one niczym wielkim - to lekcje, które odebrałem, wprawiając własne ciało w ruch i przekonując się dzięki temu, że cierpienie jest wyborem. Być może nauk tych nie da się uogólnić, a jeśli tak, to dlatego, że przedstawiam tutaj siebie, takiego, jakim jestem (2010: 8).

Tego typu rozważania jednoznacznie prowadzą nas ku filozoficznym aspektom aktywności fizycznej, którymi zajmował się R. Shusterman. Bieganie jest tu traktowane jako forma refleksji, ale też samorozwoju. Sam R. Shusterman podkreślał, że doświadczenie jest istotne dla estetyki, częściowo dlatego, że przyjemności (a mówiąc ogólniej - intensywne doznania) są ważne, a takie doznania są niezaprzeczalnie zmysłowo poznawane (Shusterman 1998: 52). To z kolei prowadzi nas do opinii wyrażonej przez jednego z komentatorów R. Shustermana, według którego doświadczenie estetyczne nie jest zamknięte wyłącznie w ściśle przeznaczonych do tego instytucjach. Człowiek nie jest ograniczony do chodzenia do muzeum i czytania krytyki artystycznej w celu posiadania głębokiego znaczeniowo przeżycia estetycznego, ponieważ somaestetyka pokazuje, jak ciało danej osoby może być przemienione w lokum wartości estetycznej (Mullis 2006: 104). Koresponduje to też z tezą innego interpretatora myśli R. Shustermana, według którego życie powinno być często oceniane z estetycznego, nie zaś moralnego punktu widzenia (Nehamas 1998: 50). Cytowany autor stwierdza też, że często właśnie tak się dzieje, ale nie pozwalamy sobie na zaakceptowanie tego faktu.

Bieganie jest jednak dla $\mathrm{H}$. Murakamiego przede wszystkim formą poprawy siebie jako człowieka, co doskonale koresponduje z myślą R. Shustermana. Według omawianego pisarza:

Bieganie jest dla mnie pożytecznym ćwiczeniem, a jednocześnie pożyteczną metaforą. Biegając dzień po dniu, biorąc udział w kolejnych wyścigach, stawiam sobie poprzeczkę coraz wyżej, a żeby ją przeskoczyć, muszę nad sobą pracować, sam siebie ulepszyć. Przynajmniej po to wysilam się każdego dnia: by podnieść wymagania względem siebie. Nie jestem w żadnym razie doskonałym biegaczem. Znajduję się na zwykłym, może nawet bardzo przeciętnym, poziomie. Ale nie o to chodzi. Chodzi o to, czy byłem, czy nie byłem lepszy niż wczoraj. W biegach długodystansowych jedynym przeciwnikiem, jakiego ma się do pokonania, jesteśmy my sami i to, jacy byliśmy wczoraj (Murakami 2010: 17).

Dzięki takiemu podejściu ludzkie życie nabiera wymiaru filozoficznego, jakie przypisywali mu omawiani powyżej greccy filozofowie, wszak dążenie człowieka nie tylko do poznania, ale i transformacji siebie określa filozoficzne życie, oddane wzbogacającemu cielesnemu doskonaleniu (Jamroziakowa 2006: 175). Jednak pojawia się tu też pewien paradoks samokreowania (paradox of self-styling). Jest tak, 
gdyż w procesie ustalania, kim się jest, trzeba niejako stać się tymczasowo kimś innym i zarazem lepszym, niż było się poprzednio, a więc autentyczne "Ja" jest również perfekcjonistycznym „Ja” (Haskins 2002: 96). Bieganie jest też po prostu formą egzystencji, co znajduje wyraz w innym cytacie z książki Murakamiego, w którym autor odwołuje się do słynnego zdania Kartezjusza: „Najpierw był bieg, a dopiero po nim towarzyszący mu byt, którym przypadkowo byłem ja. Biegnę, więc jestem" (2010: 123).

\section{Literatura}

Abrams J., 2004, Pragmatism, Artificial Intelligence, and Posthuman Bioethics: Shusterman, Rorty, Foucault, "Human Studies" 27.

Allen-Collinson J., Hockey J., 2006, Seeing the way: visual sociology and the distance runner's perspective, "Visual Studies. Journal of the International Visual Sociology Association" 21 (1).

Allen-Collinson J., Hockey J., 2015a, Digging in: The Sociological Phenomenology of 'Doing Endurance' in Distance-Running, http://www.academia.edu/17203554/Digging_in_The_sociological_phenomenology_of_doing_endurance_in_distance-running_in_W_Bridel_P_Markula_and_J_Denison_eds_Endurance_Running_A_Socio-Cultural_Examination._London_Routledge_pp_227242 [dostęp: 1.04.2017].

Allen-Collinson J., Hockey J., 2015b, From a Certain Point of View: Sensory Phenomenological Envisionings of Running Space And Place, „Journal of Contemporary Ethnography" 44 (1).

Allen-Collinson J., Hockey J., 2017, Running a Temperature: Sociological-Phenomenological Perspectives on Distance Running, Thermoception and 'Temperature Work', http://www.academia. edu/30030393/Hockey_J_and_Allen-Collinson_J_2017_Running_a_temperature_sociologicalphenomenological_perspectives_on_distance_running_thermoception_and_temperature_ work_in_A_C_Sparkes_ed_Seeking_the_Senses_in_Physical_Cultures_Sensual_scholarship_ in_action._London_Routledge_42-62 [dostęp: 1.04.2017].

Allen-Collinson J., Vaittinen A., Jennings G., Owton H., 2016, Exploring Lived Heat, 'Temperature Work' and Embodiment: Novel Auto/Ethnographic Insights from Physical Cultures, "Journal of Contemporary Ethnography", http://journals.sagepub.com/doi/pdf/10.1177/0891241616680721. [dostęp: 1.04.2017]

Guerra G., 2002, Practicing Pragmatism: Richard Shusterman's Unbound Philosophy, „The Journal of Aesthetic Education" Vol. 36, No. 4.

Haskins C., 2002, Enlivened Bodies, Authenticity, and Romanticism, "The Journal of Aesthetic Education" Vol. 36, No. 4.

Higgins K., 2002, Living and Feeling at Home: Shusterman's "Performing Live", "The Journal of Aesthetic Education" Vol. 36, No. 4.

Jakubowska H., Nosal P. (red.), 2017, Socjologia sportu, Warszawa: Wydawnictwo Naukowe PWN. Jamroziakowa A., 2006, Sztuka życia a kondycja fizyczna człowieka, "Estetyka i Krytyka" 9/10 (2/2005-1/2006).

Jay M., 2002, Somaesthetics and Democracy: Dewey and Contemporary Body Art, "The Journal of Aesthetic Education" Vol. 36, No. 4.

Johnston J. 2004, Reflections on Richard Shusterman's Dewey " "The Journal of Aesthetic Education" Vol. 38, No. 4. 
Małecki W., 2007, O praktycznych aspektach estetyki Richarda Shustermana - sztuka popularna i somatoestetyka [w:] Wizje i re-wizje: wielka księga estetyki w Polsce, red. K. Wilkoszewska, Kraków: Universitas.

Mullis E. 2006, Performative Somaesthetics: Principles and Scope, "The Journal of Aesthetic Education" Vol. 40, No. 4.

Murakami H., 2010, O czym mówię, kiedy mówię o bieganiu, tłum. J. Polak, Warszawa: Muza.

Nehamas A., 1998, Richard Shusterman on Pleasure and Aesthetic Experience , „Journal of Aesthetics and Art Criticism" Vol. 56, No. 1.

Shusterman R., 1998, Interpretation, Pleasure, and Value in Aesthetic Experience, "The Journal of Aesthetics and Art Criticism" Vol. 56, No. 1.

Shusterman R., 1999, Somaesthetics: A Discpilinary Proposal, "The Journal of Aesthetics and Art Criticism" Vol. 57, No. 3.

Shusterman R., 2002, Home Alone? Self and Other in Somaesthetics and "Performing Live", "The Journal of Aesthetic Education" Vol. 36, No. 4.

Shusterman R., 2004, Complexities of Aesthetic Experience: Response to Johnston, „The Journal of Aesthetic Education" Vol. 38, No. 4.

Shusterman R., 2007, Myślenie poprzez ciało. Rozwinięcie nauk humanistycznych - uzasadnienie dla somaestetyki, tłum. S. Stankiewicz [w:] Wizje i re-wizje: wielka księga estetyki w Polsce, red. K. Wilkoszewska, Kraków: Universitas.

Shusterman R., 2010, Świadomość ciała: dociekania z zakresu somaestetyki, tłum. W. Małecki, Sebastian Stankiewicz, Kraków: Universitas. 